\title{
Introduction: New Directions for African Agriculture
}

\author{
Ian Scoones, Stephen Devereux and Lawrence Haddad
}

\section{Introduction}

This year's UN Millennium Report highlights the lack of progress in achieving the Millennium Development Goals (MDGs) in sub-Saharan Africa. The Commission for Africa report (2005) similarly highlights the major challenges of poverty reduction on the continent. What role should agriculture have in this challenge? Most of Africa's poor are rural, and most rely largely on agriculture for their livelihoods. Inevitably, "getting agriculture moving" must be part of the solution to the seemingly intractable problem of African poverty.

The standard storyline about African agriculture is not positive. In most countries, the sector is slowgrowing or stagnant, held back by negligible yield growth, poor infrastructure, degrading environmental resources, erratic weather, HIV/AIDS and civil conflict. But sweeping, generalised analyses often hide important stories of success. As Toulmin and Guèye (in this IDS Bulletin) highlight for West Africa, there have been some notable achievements in the past decade. This is replicated elsewhere, as Wiggins observes (also in this IDS Bulletin), where supplyled successes - including in hybrid maize, horticulture, dairy, cassava (see also Haggblade and Gabre-Madhin 2004) - have combined with new sources of demand, due to improvements in infrastructure, changing market conditions or the opening up of niche opportunities.

Are these successes exceptional and limited to particular settings and times, or are they replicable across wider areas, benefiting larger numbers of people? This IDS Bulletin draws together contributions from a diverse range of researchers and development practitioners working in Africa, with the common goal of exploring why agriculture is contributing to poverty reduction and livelihood improvement in some places, but not in many. Identifying ways forward implies moving away from failed past prescriptions, identifying and building on current successes and encouraging new and innovative thinking about future pathways and opportunities.

This debate comes at a critical time. As the African Union's Commissioner for Agriculture and Rural Economy notes in the foreword to this IDS Bulletin, there is renewed interest in agriculture in Africa and a real commitment to revitalise the sector. This comes from numerous sources - whether from international initiatives such as the UN Millennium Project's Task Force on Hunger (2005) or the Commission for Africa report (2005); from within Africa, such as the African Union and NEPAD's (New Partnership for Africa's Development) Comprehensive Africa Agriculture Development Programme (CAADP) (NEPAD 2003), from national governments themselves or from the international donor community (USAID 2004; DFID 2003; World Bank 2002). But how to translate these words into reality? How to avoid the recycling and repackaging of old - and often failed - ideas? How to generate new thinking, rooted in African contexts and ground realities, which makes a difference? The aim of this IDS Bulletin is to contribute to this journey.

The central puzzle is: Why is African agriculture (largely) stagnating? This question is not new. Many have commented on the failures of an African "green revolution", and many explanations have been suggested. The following sections outline three responses: "technical fixes", "market and institutional fixes" and "policy fixes". Each approach reflects a different way of looking at the problem, and each implies different ways forward. The IDS Bulletin draws on insights from across sub-Saharan Africa and is organised as follows. Three scenesetting articles follow this introductory piece. Then there are clusters of articles focusing on "resources and technologies", "markets and institutions" and "policies and policy processes". These sections are

IDS Bulletin Vol 36 No 2 June 2005 @ Institute of Development Studies 
followed by a final set of articles on "contexts, pathways and scenarios", where individual cases examine how resources, technologies, institutions, markets and policies combine to push agriculture and rural livelihoods in different directions.

\section{Technical fixes: resource inputs and "green revolutions"}

Perhaps the most common diagnosis of the problems of African agriculture focuses on input constraints: too little irrigation, high-yielding seed, inorganic fertiliser, draught power, credit, and so on. With a production function model in mind, the solutions seem straightforward: provide more dams and irrigation schemes; improve seed varieties (including biotechnological options, such as transgenics); subsidise fertiliser; microcredit; extension and training. The list is familiar (IAC 2004; Eicher 2003) and has been at the centre of agricultural support programmes for decades.

In many cases, delivering inputs has produced the desired outputs - farm production has increased, per capita food supply and income levels have improved and poverty rates have fallen (MeinzenDick et al. 2004). But the history of technical interventions in Africa is also littered with discouraging and well-documented failures. Too often the argument for technical inputs is derived from generic "expert" assumptions, rather than a detailed analysis of farm-level constraints, in particular livelihood settings. These assumptions are often based on spurious analogy (for instance, that Asia's green revolution can be replicated in Africa) or inappropriate evolutionary models (e.g. Africa is expected to progress through the same "stages of development" that Europe followed in past centuries (Cowan and Shenton 1996)).

Africa is different - in its geography, agro-ecology, history, politics and culture - and is immensely diverse. Yet generalised, ill-informed visions of development have dominated intervention strategies, backed up by narratives about "progress", "success" and "modern" farming. As Scoones (this IDS Bulletin) shows, such approaches constrain research agendas and limit technological horizons, as when the "ideal" form of crop-livestock integration is assumed to be a standard version of "mixed farming" (Scoones and Wolmer 2002). Similar assumptions about "backward" pastoral livelihoods have also resulted in misguided livestock policies - for example restrictions on movement, or forced sedentarisation - as Catley and colleagues (this IDS Bulletin) demonstrate.

A number of articles in this IDS Bulletin focus on input constraints in agriculture. Movik et al. discuss water management and irrigation, asking what type of "blue revolution" is needed to complement "green revolutions" in agriculture. This raises questions not only about appropriate technologies and infrastructure investment, but also about institutional and social issues. Jones discusses the challenges of technology development and delivery from the perspective of the Forum for Agricultural Research in Africa, arguing that there is an urgent need to rebuild African agricultural research and development capacity, in order to enable innovation that serves the needs of the majority. This, he concludes, will require bold new programmes and new ways of organising and governing the innovation process, from upstream research to downstream implementation. Other contributors highlight the importance of road infrastructure in providing access to markets for agricultural products. DeGrassi looks at the experience of road-building in Africa and concludes that the technical and economic focus in most analyses of transport policy have obscured the social and political dimensions. Taking these dimensions into account requires significantly qualifying the conventional wisdom, that "more roads means more development".

All these articles re-emphasise the importance of agricultural inputs - technology, water, infrastructure - but all offer a note of caution. No single input will provide the desired output on its own; much depends on what types of inputs, where, for whom and whether they address the relevant limiting constraints. Unfortunately, as these authors highlight, it is often assumed that technologies are neutral and that their benefits will somehow be realised. This is not necessarily so. Interventions have differential impacts. There are winners and losers, and diverse political, social and environmental consequences.

Following a growing critique of technology-led development, these articles highlight the need for a fuller assessment of social, political and environmental consequences of development investments. Intermediary factors - social relations, politics, institutions - all imbued with power relations, and the interaction of interlocking constraints, all affect how inputs (technologies and 
development interventions) and outputs (development outcomes, including poverty reduction) are related. In their contribution to this IDS Bulletin, Fairhead and Leach remind us of the extensive literature on African agrarian systems and the importance of taking the social - in its broadest sense - seriously. They highlight how social and cultural relations shape agricultural production and investment, the type of technologies employed and the operation of agricultural markets. For example, cropping patterns or marketing choices are not the result of a single economic calculus, but are the outcome of negotiation between husbands and wives, between co-wives and between them and their children (cf. Guyer and Peters 1987). Richards and Bah (this IDS Bulletin) highlight the importance of social reforms, if the sources of vulnerability and disenfranchisement that led to conflict and war in Sierra Leone are not to recur. Reforms of land rights, marriage and local courts need to be combined, they argue, with more conventional inputs such as schooling and skills training, if rural youth and women are to feel secure enough to return to rural production and rebuild their livelihoods outside the clutches of oppressive patronage arrangements.

Despite the richness of studies on the social dimensions of agrarian settings (e.g. Peters 2004; Pottier 1999; Guyer 1997; Nyerges 1997; Berry 1993, among many others), they have had relatively little impact on mainstream policy debates about Africa, mainly because of the dominance of other disciplinary specialisms. Agricultural economists, together with agricultural scientists and technologists - supported by mainstream institutions such as the World Bank and CGIAR (Consultative Group for International Agricultural Research) - have dominated policy debates since the 1960s. They have advocated input-focused intervention strategies, addressing farm-level supply-side constraints to boost agricultural productivity, largely based on farm-level production function models. Such approaches have many merits. But, apart from overlooking the social, political and institutional processes affecting outcomes, such economic analyses may also miss broader patterns and longer term trends which impinge on input choices and output scenarios, but are not easily incorporated in a farm-level view.

For example, as Vogel discusses, climate change has not yet been adequately integrated into agricultural analyses and projections, despite the insights from global circulation models and scenarios, and a growing number of studies demonstrating the likely impacts that climate change will have on agricultural livelihoods in Africa (see Sokona and Denton 2001). In the same way, agricultural development experts and African governments were slow to realise the full consequences of the HIV/AIDS pandemic when it first emerged in the 1980s. Drinkwater documents how HIV/AIDS has affected agriculture in central Zambia, resulting in changed cropping patterns, heightened nutritional problems, social fragmentation and accompanying loss of rights and dignity.

Climate change and HIV/AIDS are just two examples of wider trends that are having major impacts on agricultural production and livelihoods in Africa. Assessing what inputs are appropriate for which setting over which time period has become a more sophisticated task than can be adequately captured within an input-output modelling framework. Rethinking is needed in a number of ways, including:

- challenging inappropriate assumptions about what "farming" is about, and avoid being misguided by simplistic versions of modernisation theory

- emphasising the social, political and institutional dimensions of technical change

- highlighting agro-ecological questions and environmental impacts and influences, including climate change

- interrogating "whose knowledge counts" - not just in disciplinary terms, but by drawing more on local understandings of complex contexts

- recognising that technical change, while necessary, is not neutral - it carries major social and political commitments, and major consequences for governance.

This has two major implications for the future:

- The need to embrace new disciplinary perspectives (beyond agricultural economics and agricultural science) to include social, political, health, environmental and other analysts in technology development and policy assessment.

- The need to highlight the key challenge of governing technical change, from upstream design to downstream delivery and regulation. 


\section{Market and institutional fixes: "getting prices and institutions right"}

For much of the 1980s and 1990s, a uniform view dominated donor thinking about agriculture in Africa. Promoted aggressively by the international financial institutions, Washington Consensus policies focused on "getting the state out" and "getting prices right". These ideas translated into policies of market liberalisation, including parastatal abolition or commercialisation, and removal of input subsidies. Many countries resisted these reform packages, by phasing implementation, renegotiating funding conditionalities, or indulging in bureaucratic foot-dragging. But, with few exceptions, agricultural reforms based on "market fix" thinking were implemented across Africa (Ponte 2002).

As several contributions to this IDS Bulletin note, the consequences for rural livelihoods have been highly variable. Some places and certain (mainly export) crops have enjoyed production and income gains. In Kenya, horticulture has been an economic success. In West Africa, cocoa smallholders saw significant growth for many years, and cotton has grown strongly in parts of the Sahel. For those who are well connected to effective markets and have products to sell for good prices, liberalisation has had positive impacts. But even the success stories have their downside. As Barrientos et al. discuss for Kenya and South Africa, opportunities for accessing markets are limited, and the profits enjoyed by the export horticulture businesses may be at the expense of labourers - especially women - who are offered poor conditions and low wages. West Africa's traditional export commodities - cocoa, coffee, cotton - have been hit hard by falling prices on international markets, growing competition from elsewhere and disrupted production due to conflict. In the case of cotton, the challenge of producing high-quality fibre for export is enormous, especially in a market where US competitors have received vast subsidies (Watkins and Sul 2002).

In Africa's rural hinterlands, where most poor farmers live, the story has been even less positive. A number of articles in this IDS Bulletin reflect on this experience. Devereux et al. argue that various radical efforts to boost agriculture in Ethiopia including land redistribution and resettlement programmes - have mostly failed, and smallholders in highland areas remain as vulnerable as ever. White et al. discuss Zambia, where farmers have diversified into cash crops in some provinces, but in others have reverted from maize production to cassava, and are worse off after agricultural liberalisation than before. In Southern Africa in general, Cromwell and Chintedza argue that "neopatrimonialism" - where political authority is based on the giving and granting of favours - has undermined accountability and processes of policy implementation. The consequence has been increased livelihood vulnerability, with the food crisis of 2002 being a significant repercussion.

Thus, for a variety of reasons, the gains from liberalisation in Africa have been patchy, limited or absent. Poorer farmers have lost the support once offered by (admittedly inefficient and often corrupt) parastatal marketing boards and government research and extension systems, but have rarely gained new support, markets or production opportunities. The consequence has been increased impoverishment for many, and growing inequalities between those who have gained and those who have been marginalised.

What are we to make of this rather dismal assessment? The World Bank and other donors have begun to re-think (e.g. World Bank 2003). Is liberalisation really the route to pro-poor growth in the agricultural sector? Some continue to argue that the medicine is correct, but the patient is at fault - the reforms have not been sequenced well, they have not been implemented properly, other factors (corruption, conflict, bureaucratic delay, "cultural" impediments) have got in the way (Jayne et al. 2002).

But other alternatives are emerging. Dorward et al. (this IDS Bulletin) lay out an argument for a mix of strategies: getting prices right does matter, but so does getting institutions right, and this must be preceded by putting certain basic conditions in place (including infrastructure and land reform). The primary diagnosis, however, is institutional. Markets cannot be expected to work as the textbooks predict, Dorward and colleagues argue, if coordination is weak and institutions are missing, because these increase transaction costs and encourage market failure. Addressing coordination and market failures, they argue, requires support for regulated monopolies, franchises, trader and farmer associations, combined with price guarantees, price support and/or input/output/credit 
subsidies. This approach provides an important progression from the extreme neoliberalism of the Washington Consensus, defining a route to propoor agricultural growth that takes account of the complexities of local implementation and the need to invest in institutional innovation.

Others would argue that this response is still too limited, not least because it draws heavily on "new institutional economics" thinking, which is silent on issues of politics and power. As Fairhead and Leach argue, the social and political dimensions of "real" markets and institutions are crucial (de Alcantara 1993; Mehta et al. 1999), since "coordination" and "transactions" are as much social and political issues as they are economic. This argument can be illuminated through examining particular experiences with market reforms. In their article, Cromwell and Chintedza point to a pattern of patronage-based politics, which is so embedded in political, bureaucratic and donor aid systems in the Southern Africa region that it inevitably compromises the outcome of any reform.

Several contributors argue that globalisation has altered the structural and power relations that shape global agriculture to such a degree that local-level institutional coordination simply tinkers at the margins. Olukoshi, for example, stresses the urgency of recapturing the development agenda from an African perspective, arguing that following external models has contributed to an emergent crisis, where increasing poverty, inequality and disenfranchisement are leading to political instability and conflict. Olukoshi sets out an agenda for "investing in Africa" which goes well beyond an "institutional fix", to the heart of politics and governance. A similarly wide-ranging challenge is laid down by Mulvany's article on the globalisation of seed systems, which argues that the capture of genetic resources by a restricted number of global multinationals is a major threat to livelihoods in Africa. Mulvany argues for a reassertion of farmers' rights and for the development of food systems that enhance food sovereignty. Similarly, Amanor argues that agribusiness is starting to dominate the profitable agricultural sectors, squeezing out others in the process. As a consequence, a dualistic scenario is emerging, where wealthy entrepreneurs, linked to foreign capital and connections to political elites, are making money from agriculture, but others are languishing behind. All these contributions suggest the need to focus development efforts not just on technical, economic and institutional policy measures, but to pay more attention to more fundamental political processes of agrarian reform.

This dualistic model of a vibrant commercial agriculture, engaging with world markets, attracting external investment, meeting sanitary and phytosanitary (SPS) standards and earning foreign currency, alongside a struggling smallholder sector that gradually withers away over time, is consistent with a "modernisation" view of African agriculture that is popular with many African governments and donors (cf. Jaffee et al. 2003). But how likely is it that new commercial entrants in Africa will survive in the cut-throat world of global agriculture markets? Can SPS standards realistically be met by African farmers and pastoralists, as these standards are ratcheted ever upwards by importing countries? Will African governments have the capacity to take others to World Trade Organization (WTO) dispute panels without retribution or penalty? Will the playing field ever be truly level?

As Barrientos et al. observe, supply chain requirements are increasingly stringent and the competition is fiercer than ever, forcing African enterprises to push down their costs, undermining wages and working conditions, and displacing livelihood opportunities for many producers and workers. The implications for poverty reduction are not encouraging, even for those operating in niche markets (e.g. organic, GM-free, or fair trade). In his article, Stevens argues that the conditions for trade under the WTO are effectively set, but that there is limited room for manoeuvre around key areas. He makes the case for an African focus on "special differential treatment" arrangements, so that inappropriate rules can be vetoed or avoided. In parallel there is an urgent need to discuss what international rules African agriculture needs, so that in future rounds of negotiation African perspectives can get a look in. For now, however, the global system - despite some preferential access and special agreements - is stacked against African export agriculture, except in a few traditional commodities (although these are coming under pressure from other producers - cocoa from Indonesia and Malaysia, coffee from Brazil, beef from Argentina), and a few niche areas (such as horticulture or floriculture).

The benefits of a strong commercial export sector have been advocated to justify the continuation of dualistic agriculture in former settler colonies in 
Southern Africa. But, as Zimbabwe has shown (and Namibia and South Africa might, in time), this dualism can become politically untenable if the distribution of benefits and resources (especially land) remains excessively skewed. Studies have highlighted the potential contributions of smallholder farming in agricultural growth and noted how the trickle-down benefits from largescale commercial agriculture are often limited (IFAD 2001; Lipton 2004). Catley et al. describe the challenges faced by the pastoral livestock sector too. Meeting export requirements has driven the design of livestock projects in Africa since the 1960s. But is achieving European Union import requirements realistic? Are extensive disease-free zones feasible in southern Ethiopia, Somalia or Sudan, when they are so difficult to maintain even in the highly controlled conditions of South Africa or Namibia? Are there other ways of thinking about agricultural trade options for Africa?

Perhaps agricultural trade - and the tangible benefits of commercialisation - can be boosted in Africa in more innovative ways. Catley et al. offer an instructive example. Ensuring that individual livestock commodities are disease-free is considerably easier than eliminating disease over large land areas, so why not engage in commoditybased trade and encourage standard-setting organisations and importing countries to accept this route to achieving SPS standards? World markets are changing, sources of demand are shifting and there may be opportunities closer to home. Diao et al. (2003) estimate that potential demand for agricultural products in Africa far exceeds supply, but trade is constrained at present by inappropriate barriers, poor transport and lack of information. Some African governments have initiated 'look east' policies, making connections with Asia (particularly India and China), the Middle East and North Africa for supplying products, sometimes through complex barter deals. These markets, still under-explored, offer a future for African agriculture that is not tied so far to conventional, more restrictive trade relationships.

Leaving aside the commercial viability of exportoriented agriculture under today's global market conditions, others argue that the social and political consequences of increasing inequality within agriculture are of even greater concern. As both Amanor and Olukoshi note, tensions are rising in many countries between the smallholder majority and a new commercial elite - often deeply intertwined with a new political elite - and the resolution of these tensions may not always be nonviolent or democratic. Richards and Bah (this IDS Bulletin) point out that the extent to which African civil wars have also been agrarian crises has been underestimated. By failing to address issues of agrarian injustice at the root of recent African conflicts, donors and policy-makers risk fuelling or reconstructing the causes of war.

Contributions to this IDS Bulletin highlight the need to move far beyond "getting prices right". Agricultural policy reforms must be carefully sequenced and must be complemented with (often state-backed) institutional arrangements for making markets work. This perspective brings the state back in - "state plus market" rather than "state versus market". But Africa's agricultural problems are not amenable to just a simple "institutional fix". Supplementing the "beyond liberalisation" arguments of Dorward et al., many contributions to this IDS Bulletin additionally emphasise the political and social dimensions of agricultural policy reform, arguing that:

- both states and markets have underlying social and political dynamics that define which institutional solutions will work in specific settings, and which will not.

- understanding the messy, hidden politics of policy and implementation - including forms of patronage and patrimonialism - is important for achieving realistic and accountable institutional and policy responses.

- "real" markets involve social and political actors, as do "real" institutions. Simple blueprint institutional designs will not work; instead, more adaptive, negotiated responses are required that recognise divergent interests, power and conflict.

- export-oriented agriculture may well be profitable for some commodities, but over what time-frame and at what cost? Meeting the expanding export requirements of markets may not justify the investments required, at either the private or social levels. Different strategies need to be explored, based on regional and domestic markets.

- the divide between an elite who gain from agriculture (through a combination of business acumen and political patronage) and those who do not (the rural poor majority) may result in 
conflict and division that can be difficult to contain. As Bates (1981) taught us, the path that agricultural development takes is a political choice with political consequences.

\section{Policy fixes: experts, frameworks and initiatives}

Contemporary debates about the future of African agriculture can be better understood if set in the context of previous policy debates and initiatives. Each era has had its core narrative. In the 1960s, as noted above, agricultural policy was embedded in a modernisation perspective, with technology and state-led planning leading the way. In the period following independence, this was generally combined with a nationalist, often socialist, ideology and an emphasis on nation-building, underpinned by a drive for food production self-sufficiency.

The Green Revolution in Asia, which began to show dramatic impacts from the early 1970s (Hazell and Ramaswamy 1991), was iconic and widely seen as a model for Africa: high-yielding varieties, fertilisers and irrigation, delivered through credit schemes, possibly supported by cooperatives. A switch away from colonial dependency on export commodities to supplying food for the new nation, particularly the growing urban populations, was seen as imperative. The production booms following land reform in the Kenyan highlands testified to the potential of a technology package-led approach, but such successes remained isolated and the "green revolution" failed to take off in Africa.

The 1970s saw a shift towards integrated rural development programmes (IRDPs) which linked agricultural development to credit facilities, extension support, even education and health services. IRDPs created islands of success. In Ethiopia, for example, CADU (Chilalo Agricultural Development Unit) and WADU (Wolaita Agricultural Development Unit) had positive impacts on agricultural yields, total output and general development indicators. But these gains were short-lived and not sustainable (Cohen 1987). Dependent on high levels of government (and loan) support, when the programmes were disbanded or incorporated into local government or line ministries the impacts quickly faded.

The late 1970s and early 1980s saw the advent of "farming systems research", an attempt to get away from the research station bias of "green revolution"-style technical fixes and engage with the real, complex problems of farming in the field. These analyses threw up a number of challenges. In addition to conducting adaptive research on particular technologies, the full range of interacting factors that affect agricultural production became increasingly apparent. Agricultural development had to be, at the same time, about technology generation and transfer, marketing, rural finance and credit, natural resource management; and it had important social dimensions as well - men had different priorities to women, young to old, rich to poor. Complex "recommendation domains" emerged, with research and extension (then still almost exclusively state-run) having to become more finely targeted (Collinson 2000).

During the structural adjustment era of the 1980s and 1990s, much of this investment in building research and extension capacity unravelled. Cashstrapped governments, under attack for being "too interventionist", retrenched researchers and extension workers, closed farming systems units and abandoned on-farm trials. The private sector was expected to fill the gap (World Bank 1995). In some places, for some commodities (mainly hybrid seeds and inorganic fertilisers sold to richer farmers in high potential areas), this happened. In other places NGOs - seen by donors as a new "third sector" in the 1980s - set up parallel efforts, but, as with the donor-funded IRDPs that preceded them, these projects usually resulted in small, unsustainable, islands of success.

The post-reform era is characterised by lack of government capacity in basic agricultural research and support (Chema et al. 2003; Friis-Hansen 2000). Many African farmers have not seen a government researcher or extension worker for years. In parallel, many countries have seen the emergence of a two-track agricultural sector: one profiting from new commercial opportunities, the other characterised by stagnation and poverty. Yet today, as recognition grows of the limitations of the liberalisation reform experiments, there is renewed interest in poverty reduction as the core challenge for development. Agriculture, it is argued, must be central to meeting this challenge.

A new policy architecture has emerged. The Millennium Development Goals (MDGs) provide a framework within which these new efforts are set. These set ambitious targets, supported by the African Union's CAADP, national poverty reduction strategies (PRSPs) and associated direct budget 
support mechanisms. But do these frameworks, targets, plans and programmes offer anything new? Fall and Niang (this IDS Bulletin) are sceptical from their review of country experiences in West and Central Africa. They point out that participation of the poor in PRSPs has been limited or tokenistic, and that cutbacks associated with structural adjustment reforms have undermined institutional capacity to design and implement effective poverty reduction strategies. These considerations raise real questions about whether the new policy approaches will succeed.

In the past, policy failure was explained in a number of ways. Either the policy was deemed "bad" (e.g. government support for subsidies and parastatals); or the policy was seen as "good" but was implemented or sequenced incorrectly (as argued by supporters of liberalisation (cf. Kherallah et al. 2000)). Or, it was asserted that good policies had no chance of working, given the unlevel playing field in which they were implemented. All these explanations frame the policy failure as a technical problem (poor design, faulty implementation, or external constraints), which is amenable to technical solutions. An inappropriate policy is replaced with a better one; policy implementation or sequencing is planned better; external factors upsetting the policy environment are tackled or by-passed. It is perhaps not surprising that those on the receiving end of these expert-driven policy solutions - farmers or their intermediaries in government departments across the continent - are rather bemused. They must ask themselves: what is the latest buzzword from London, Washington or Rome? How can we re-work our plans in terms of "pro-poor growth", "sustainable livelihoods" or "food security"? What must we do to get to the top of the PRSP/CAADP/CSP (Country Strategy Paper) funding priority list?

Several contributions to this IDS Bulletin (Cromwell and Chintedza; Scoones; Catley et al.) highlight the social and political dynamics of policy processes. This approach emphasises not just the technical content of policy (and its implementation), but a wider appreciation of the processes by which policies arise and are implemented (cf. Keeley and Scoones 2003), thereby allowing them to be strengthened both technically and politically. As Ascher (1984) observed in the Latin American context, "scheming for the poor" is not a simple, technical process, driven by impartial evidence and expertise, it is fundamentally political, conditioned by the historical, cultural and social characteristics of government bureaucracies, the aid machinery and their interactions with each other and with different interest groups and multiple stakeholders.

As Olukoshi argues, the implementation of economic liberalisation in Africa became inextricably linked to a parallel policy process of patrimonial politics and elite accumulation, consolidating both commercial and political interests. The consequences for the rural poor, in a context of imperfect electoral systems with limited accountability, were rarely considered. Similarly, Mulvany suggests, "technical fixes" may suit particular multinational interests in the seed and agricultural inputs industry. Whenever "pro-poor" benefits are claimed for genetically modified crops, for example, the underlying commercial and political interests must always be carefully interrogated.

Sometimes, though, self-interest is less evident, and policy processes unfold partly because no alternative is envisaged or aired. Scoones (this IDS Bulletin) offers examples of how simple "narrative" lines of argument can become deeply entrenched in ways of thinking and ways of acting. For example, highly contested policy narratives about desertification and deforestation have defined natural resource management strategies throughout Africa (Leach and Mearns 1996). This has occurred because narrow forms of expertise, routinised and locked into particular institutional settings (research organisations, government departments, aid donors, academic communities, trade organisations), remain largely unquestioned.

At the global level, the challenge of getting African perspectives heard and incorporated into appropriate standard-setting and rule-making processes - in the WTO, OIE (Office International des Epizooties) or Codex Alimentarius, for instance - is highlighted by Stevens (this IDS Bulletin). As the Commission for Africa (2005) notes, the levels of organisation, commitment, confidence and networking capacities required are often absent in African governments, and, when they are present, can be undermined by donor behaviour. The scaling back of state capacity due to economic reforms has made the challenge even harder, given high staff turnover; limited budgets for meetings and travel; inadequate access to up-to-date information and dependence on donors or outside consultants. 
Introduction: New Directions for African Agriculture

The new agrarian politics of the post-reform era presents some major challenges for the new organisational and political frameworks for African governance and development. The African Union, the Regional Economic Communities and NEPAD must each address issues of politics and policy process at multiple levels - within member states, within regional groupings and at the global level. New arguments, new strategies and new forms of political alliance are needed in favour of Africa's rural poor. What might they look like? How will they be brought about?

Several dangers exist. First, the new players in the policy game, familiar with technically driven, expert-led decision-making, may slip back into the comfortable approach of separating the technical from the political. The same consultants are available to trot out the same old lists of solutions and priorities; for some, NEPAD's CAADP, with its long list of ambitious targets, risks repeating past mistakes (Moyo 2002). Many PRSPs, as Fall and Niang observe, have failed to offer innovative approaches to agricultural support. A second danger results from the new configurations of agrarian interests forged by the economic reform and adjustment era. As Olukoshi and Amanor point out, these are not necessarily supportive of a pro-poor, smallholderled agricultural regeneration. The new elites are good at repeating the latest mantras of the donor community, but there is often a wide gulf between policy rhetoric and political action.

Confronting these challenges requires shifting the focus from technical policy content to an approach that links content to process. This brings politics to the fore. It also brings potentially new voices and perspectives to the table. This has some major implications for the way we think about and implement policy. It means, for example:

- going beyond narrowly defined technical expertise, and recognising that policies (and their implementation) must be negotiated outcomes, requiring the involvement of multiple players with different interests

- not simply resorting to exhortations about needing renewed "political will", but examining the interests and political choices underlying policy processes, and strategising around how pro-poor outcomes may be realised

- openly debating the politics of agrarian change in Africa and internationally, recognising that agrarian change (whether through national policy, donor funding or international trade agreements) is necessarily a political process

- building the capacity of "technocrats" in government ministries (but also consultants, politicians and others) to understand processes of policy change (at national and international levels), so that they can be influenced in favour of pro-poor outcomes.

\section{Livelihood contexts and scenarios}

Where does this lead us? What new avenues need to be pursued? A core challenge, emphasised by many contributors to this IDS Bulletin, is to go beyond conventional ways of thinking about African agriculture. Past debates have often been framed (unhelpfully) in terms of policy choices between dichotomous oppositions:

- Smallholder or large-scale commercial agriculture?

- "Subsistence" or market-oriented agriculture?

- Cash crops or staple food crops?

- Subsidised inputs or the free market?

- State-delivered services or private sector delivery?

- International export trade or domestic and regional trade?

- Agricultural intensification or off-farm diversification?

All too often these debates reach the same appropriate but unhelpful conclusion: it all depends. No single scenario is inevitable, no single policy solution is appropriate. We can - and must - get beyond the sterile generalities of such policy debates. As Olukoshi argues, we must engage with specific and complex livelihood contexts in different places. Instead of developing policy solutions from topdown arguments and models, policy solutions must emerge out of the diversity and variety of local contexts. From this analysis we can then ask: what patterns are emerging? Can any typologies, trajectories, pathways or scenarios be drawn out?

A number of articles in this IDS Bulletin attempt elements of such an analysis. Each concludes with a nuanced version of the "classic" debates, but are not framed by them. Thus for instance, Bahiigwa et al. argue for Uganda and Tanzania that the pattern of "de-agrarianisation" (cf. Bryceson 1996) and livelihood diversification is inevitable. Rather than trying to stem 
the flow, policies need to support those leaving the land, and refocus on agriculture in different ways for those who remain as rural producers. A similar "pathways" analysis is set out for highland Ethiopia by Devereux et al., who argue that different sets of farmers should be assisted to pursue different livelihood strategies, with some intensifying their farming, while others diversify away from agriculture and others are facilitated to resettle if and where land is available. In one scenario, a selective regeneration of agriculture by entrepreneurial smallholders might be feasible, but only if these farmers are given the opportunity to escape the "low-level equilibrium trap" (cf. Dorward et al., this IDS Bulletin) by accumulating the land and productive inputs they need to become surplus producers.

Cousins and Lahiff raise the question of what type of farming is needed in South Africa. Their argument for a redistributive land reform to allow smallholder farming to take off highlights the importance of getting away from defining agriculture and farming in constrained and conventional ways. Many studies from South Africa and elsewhere demonstrate low production and low productivity in the smallholder sector. But such statistics may miss the point. With many rural dwellers engaging in diverse livelihood activities - either out of choice or necessity - farming may be just one part of a portfolio of activities. Farmers are not farmers in the standard mould, so they do not respond to policies and interventions as they are "supposed" to. This is not because they are "irrational", "backward" or "non-modern", but because policy is out of step with ground realities, as Fairhead and Leach explain with examples from West and Central Africa.

Richards and Bah argue that in the post-conflict settings of Liberia and Sierra Leone, agriculture should be seen as central to the peace-building process. But, again, the choice of technologies, involvement of social groups and processes of institutional change all have to be thought about in relation to the evolving social, political and livelihood context. Their article highlights the centrality of marriage institutions, labour relations and gender disempowerment as key factors in both agrarian relations and conflict, arguing for fundamental reforms if impoverished rural women and youth are to re-engage with rural production.

The challenges of rebuilding agriculture after economic reform are explored for Zambia by White et al. They trace the transition from a relatively successful government-supported white maize sector in the 1980s to a process of agricultural involution and impoverishment after state support was withdrawn. While some farmers have successfully diversified into new cash crops and some have taken part in cotton out-grower schemes, other parts of the country have been left behind. In these areas, lack of access to inputs (such as fertiliser and credit) and the absence of private commercial actors has contributed to agricultural stagnation, presenting a very different agricultural development challenge to a few years before.

Each of these cases - located in particular settings, based on both technical and social assessments of livelihood dynamics - concur that there are different ways of getting people out of poverty. Just as there are "no short-cuts to progress" in Africa (cf. Hyden 1983), so there are no short-cuts to pro-poor policy solutions. The terminology of pro-poor (or profarmer, or pro-female) has recently become embedded in policy discourse. While all such policies are seen as "good" (who supports an antipoor policy?), what counts as "pro-poor" is often less than clear. With heroic assumptions about trickle-down effects to poorer households, virtually anything, it seems, can be justified.

\section{New directions?}

So where does this leave us? What new directions are needed? A number emerge from the articles in this IDS Bulletin. Key conclusions include:

- Generic policy assessments are less useful than commonly thought for policy formulation and implementation. Policy assessments must always build on context-specific analysis.

- Detailed assessments of interlocking sets of constraints to agriculture - at local, national and regional levels - must be developed from location-based analyses. This will require investments in local-level innovation systems. As the Commission for Africa notes (2005: 45): 'What Africa's agricultural success stories show is that there is no single "key" to unlock agricultural growth. As with so much in Africa, interventions have to take place simultaneously in a number of areas'.

- Typologies and scenarios should be developed for each context that go beyond simple either/or oppositions, but offer different options for different groups of people in different places. 
- Methodological development for such work including the building of capacity of researchers and policy-makers to undertake such analysis themselves - requires serious investment, both from within Africa and from donor countries.

- The international and national agricultural establishment must be encouraged to think more creatively about the problem-solving process in African agriculture and their place within it who frames the questions, whose knowledge counts, what models of innovation and policy formation are most appropriate, whose capacity is engaged and enhanced in the development of solutions and policies, how is impact identified, defined and measured, and how is the learning from that assessment demonstrated?

There is of course no magic bullet for the problems of African agriculture: no technical, market, institutional or policy fix. The articles in this IDS Bulletin make the case for looking at context and particular settings before jumping to conclusions about what to do. We must also go

\section{References}

Ascher, W., 1984, Scheming for the Poor: The Politics of Redistribution in Latin America, Cambridge, MA: Harvard University Press

Bates, R., 1981, Markets and States in Tropical Africa. The Political Basis of Agricultural Policies, Berkeley: University of California Press

Berry, S., 1993, No Condition is Permanent: The Social Dynamics of Agrarian Change in Sub-Saharan Africa, Madison, WI: The University of Wisconsin Press

Bryceson, D., 1996, 'Deagrarianization and rural employment in sub-Saharan Africa: a sectoral perspective', World Development, Vol 24 No 1: 97-111

Chema, S., Gilbert, E. and Roseboom, J., 2003, 'A review of key issues and recent experiences in reforming agricultural research in Africa', Research Report 24, The Hague: International Service for National Agricultural Research (ISNAR)

Cohen, J., 1987, Integrated Rural Development: The Ethiopian Experience and the Debate, Uppsala: The Scandinavian Institute of African Studies

Collinson, M.P. (ed.), 2000, A History of Farming Systems Research, Wallingford: CAB International and Rome: Food and Agriculture Organization beyond recycling redundant ideas and learn from past failures. This is not to say that "old" ideas have no utility. The collection of solutions suggested in this IDS Bulletin include some very old ideas (e.g. feeder roads, irrigation systems, state-led land reform, input subsidies, price stabilisation and so on), but, importantly, qualified in new ways. Central to all solutions are social, cultural and political factors. Rather than an expert-driven, technocratic approach, a more politically sophisticated stance is required. A new emphasis therefore needs to be on understanding and influencing processes of innovation, intervention and policy, not just their technical content. Such an approach requires a cross-disciplinary approach - bringing the best of economic and technical analysis together with insights from socio-cultural and political analysis. It also requires a thoroughly grounded approach, rooted in context-specific constraints analysis, allowing for scenarios and options to be elaborated and debated by the multiple stakeholders involved in the future of African agriculture.

Commission for Africa, 2005, 'Our Common Interest. Report of the Commission for Africa'. Available at www.commissionforafrica.org (accessed 1 April 2005)

Cowan, M. and Shenton, W., 1996, Doctrines of Development, London: Routledge

de Alcantara, H., 1993, Real Markets: Social and Political Issues of Food Policy Reform, London: Frank Cass/European Association for Development Research and Training Institutes (EADI)/United Nations Research Institute for Social Development (UNRISD)

DFID, 2003, Agriculture and Poverty Reduction: Unlocking the Potential, London: Department for International Development

Diao, X., Dorosh, P. and Rahman, S., 2003, 'Market opportunities for African agriculture', DSGD Discussion Paper 1, Washington, D.C.: International Food Policy Research Institute

Eicher, C.K., 2003, 'Flashback: fifty years of donor aid to African agriculture', Successes in African Agriculture Conference Paper 16, Washington, D.C.: International Food Policy Research Institute

Friis-Hansen, E., 2000, 'Agricultural policy in Africa after adjustment', CDR Policy Papers Series, Copenhagen: Centre for Development Research 
Guyer J., 1997, An African Niche Economy: Farming to Feed Ibadan 1968-88, Edinburgh: Edinburgh University Press

Guyer, J. and Peters, P. (eds), 1987, 'Conceptualising the household: issues of theory and policy in Africa', Development and Change, Vol 18 No 2: $197-213$

Haggblade, S. and Gabre-Madhin, E., 2004, 'Successes in African agriculture: results of an expert survey', World Development, Vol 32 No 5: 745-66

Hazell, P. and Ramaswamy, C., 1991, The Green Revolution Revisited, Baltimore: Johns Hopkins University Press

Hyden, G., 1983, No Shortcuts to Progress: African Development Management in Perspective, Berkeley: University of California Press

IAC, 2004, Inventing a Better Future. A Strategy for Building Worldwide Capacities in Science and Technology, Amsterdam: InterAcademy Council

IFAD, 2001, Rural Poverty Report, Rome: International Fund for Agricultural Development

Jaffee, S., Kopicki, R., Labaste, P. and Christie, I., 2003, 'Modernizing Africa's agro-food systems: analytical framework and implications for operations', Africa Region Working Paper Series No 44, Washington, D.C.: World Bank

Jayne, T.S., Govereh, J., Mwanaumo, A., Chapoto, A. and Nyoro, J.K., 2002, 'False promise of false premise? The experience of food and input market reform in Eastern and Southern Africa', World Development, Vol 30 No 11: 1967-85

Keeley, J. and Scoones, I., 2003, Understanding Environmental Policy Processes: Cases from Africa, London: Earthscan

Kherallah, M., Delgado, C., Gabre-Madhin, E., Minot, N. and Johnson, M., 2000, 'The road halftravelled: agricultural market reform in subSaharan Africa', Food Policy Report 10, Washington, D.C.: International Food Policy Research Institute

Leach, M. and Mearns, R. (eds), 1996, The Lie of the Land: Challenging Received Wisdom on the African Environment, London: James Currey

Lipton, M., 2004, 'Crop science, poverty and the family farm in a globalising world', plenary address, International Crop Science conference, Brisbane, September

Mehta, L., Leach, M., Newell, P., Scoones, I., Sivaramakrishnan, K. and Way, S.-A., 1999, 'Exploring understandings of institutions and uncertainty: new directions in natural resource management', IDS Discussion Paper 372 , Brighton, UK: Institute of Development Studies Meinzen-Dick, R., Adato, M., Haddad, L. and Hazell, P., 2004, Science and Poverty: An Interdisciplinary Assessment of the Impact of Agricultural Research, Washington, D.C.: International Food Policy Research Institute

Moyo, S., 2002, The NEPAD Agricultural Strategy. Africa's Development in the New Millennium, Dakar: CODESRIA and Accra: TWN Africa, www.twnafrica.org (accessed 1 April 2005)

NEPAD, 2003, Comprehensive Africa Agriculture Development Programme (CAADP), Midrand: New Partnership for Africa's Development

Nyerges, A.E. (ed.), 1997, The Ecology of Practice: Studies of Food Crop Production in Sub-Saharan West Africa, UK: Gordon and Breach Publishers

Peters, P., 2004, 'Inequality and social conflict over land in Africa', Journal of Agrarian Change, Vol 4 No 3: 269-314

Ponte, S., 2002, Farmers and Markets in Tanzania: How Policy Reforms Affect Rural Livelihoods in Africa, Oxford: James Currey

Pottier, J., 1999, Anthropology of Food: The Social Dynamics of Food Security, Oxford: Blackwell

Scoones, I. and Wolmer, W. (eds), 2002, Pathways of Change in Africa: Crops, Livestock and Livelihoods in Mali, Ethiopia and Zimbabwe, Oxford: James Currey

Sokona, Y. and Denton, F., 2001, 'Climate change impacts: can Africa cope with the challenges?', Climate Policy, Vol 1 No 1: 117-23

UN Millennium Project, Task Force on Hunger, 2005, Halving Hunger: It Can be Done, London: Earthscan USAID, 2004, Linking Producers to Markets: A Renewed Commitment to Agriculture. A Strategy for Agricultural Development, Washington, D.C.: US Agency for International Development

Watkins, K. and Sul, J., 2002, 'Cultivating poverty: the impact of US cotton subsidies on Africa', Briefing Paper 30, Oxford: Oxfam

World Bank, 2003, 'Sustainable development in a dynamic world: transforming institutions, growth, and quality of life', World Development Report, Washington, D.C.: World Bank

World Bank, 2002, From Action To Impact: The Africa Region's Rural Strategy, Washington, D.C.: World Bank

World Bank, 1995, 'Promoting private agribusiness activity in sub-Saharan Africa', Findings, Africa Region 50, October, Washington, D.C.: World Bank 